\title{
A CASE OF ERYTHEMA EXUDATIVUM MULTIFORME - IDIOPATHIC FORM - TREATMENT PROBLEMS
}

Asya Krasteva, Evgeniy Aleksiev, Tzveteliva Gocheva, Angelina Kisselova

Department of Imaging and Oral Diagnostic,

Faculty of Dental Medicine, Medical University of Sofia, Bulgaria

\section{SUMMARY:}

An idiopathic form of erythema exudativum multiforme, characterized by atypical localization and lack of skin manifestation at the moment of the clinical exam, was found. It was diagnosed rather late, after two biopsies of the skin and one of the oral lesion.

The authors would like to accentuate the problems of treatment of idiopathic forms their search for new solutions.

Key words: erythema exudativum multiforme, idiopathic form, treatment problems

\section{CLINICAL CASE:}

1. a 28 years old woman

2. history:

- preceding surgical intervention due to benign tumor in the cranial cavity

- current complaints:

a. erythema spots on the skin

b. Chronic recurrent lesions in the mouth and lips (every 30-40 days) - for the past two years

c. joint swelling and joint pain

d. the patient relates the start of this disease to a course of chemical teeth whitening

\section{OBJECTIVE:}
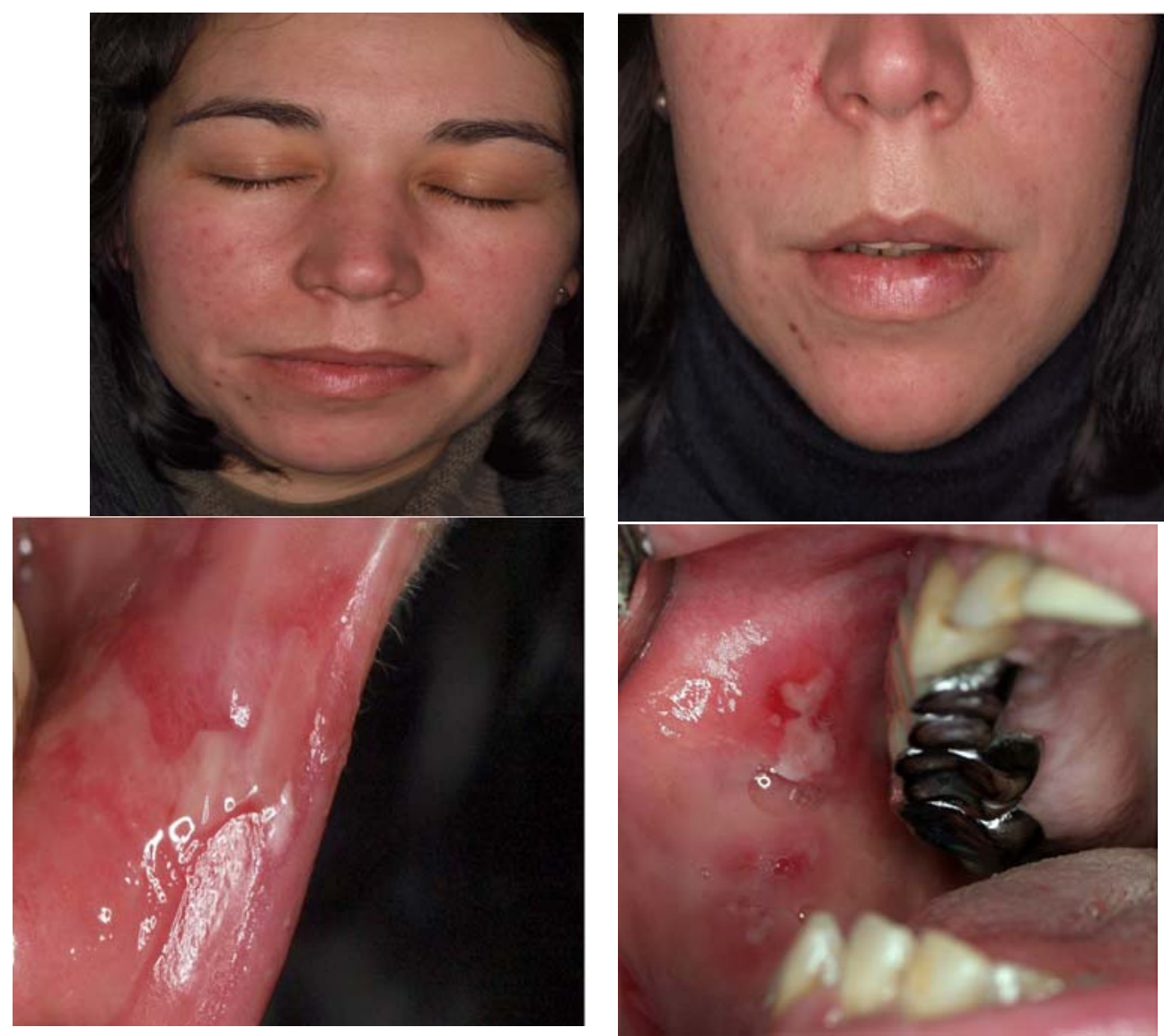
- Small rash, facial erythema

- At the first meeting - only oral findings, without affecting the lips

\section{Pending the review:}

1. two skin biopsies - unanswered

2. discussed diagnoses - lupus or erythema

3. oral lesions - therapy failure - Elokom, Aciclovir - taken for a short period of time removed the lesions, but the effect was temporary.

\section{Questions:}

1 . Why do we present a simple case?

The suffering patient, who was not diagnosed and treated properly, met a team of dental medics, after a series of unsuccessful consultations.

The role of dental medics in such cases: diagnosis

1. To urge a biopsy of the oral cavity - to assist

2. Should dental medics assign treatment? - only for the oral manifestations

3. Follow up of the patinet

\section{What was done: :}

4. biopsy from the lip lesions and oral mucosa

5. focal diagnostics, including. epi test for dental materials and pathogalvanism test

6. bacteriological examination of whole saliva and throat swabs - searching for candida, staphylococci and sterptococci
7. complete blood count and virology - herpes simplex virus (HSV)

\section{Diagnosis:}

1. Oral biopsy - indicated erythema

2. revised skin biopsy - indicated erythema

3. high IgM HSV

The diagnosis is not enough!

- Patient recommendations :

1. Mouth bath with KMnO4 1:10 000 - for antiseptic effect

2.Dentinox gel -analgesic effect - contains chamomile, glycerin and lidocaine

3. Aciclovir - for a long period - six months

4. Izoprinozin - Immunomodulator - 3x2 tablets/ daily-5 days - from the beginning of each attack

5. Lokoid topical cream

6. Tubotsin - three months, $300 \mathrm{mg}$ per day - capsules - discussed in a positive outcome for staphylococci

Now why the patient did not receive better care?

Due to lack of patience;

- Lack of results from the biopsies;

- Lack of blood test and HSV-tests

- Short-term treatment with Aciclovir and Izoprinozin for only 5 days.

Until now the patient has been in remission for the past 95 days.

\section{REFERENCES:}

1. Carrozzo M, Togliatto M, Gandolfo S. Erythema multiforme. A heterogeneous pathologic phenotype. Minerva Stomatol. 1999 May;48(5):217-26 (Article in Italian)

2. Ayangco L, Rogers RS 3rd. Oral manifestations of erythema multiforme.
Dermatol Clin. 2003 Jan; 21(1):195-205. 3. Osterne RL, Matos Brito RG, Pacheco IA, Alves AP, Sousa FB. Management of Erythema Multiforme Associated with Recurrent Herpes Infection: A Case Report. J Can Dent Assoc. 2009
Oct;75(8):597-601.

4. Lozada-Nur F., Shillitoe E.J. Erythema Multiforme and Herpes Simplex Virus. J Dent Res June, 1985 64(6):930931,

\footnotetext{
Address for correspondence:

Assya Krasteva, DM

Department Imaging and oral diagnostic, Faculty of Dental medicine - Sofia

1, G. Sofiyski Str., 1000 Sofia, Bulgaria

e-mail: asyakrasteva@abv.bg
} 